Supporting Information

\title{
Binuclear Scandium Initiators for Syndiospecific Living Triblock Copolymerization of Styrene with $\varepsilon$-Caprolactone
}

Yang Wang, ${ }^{[\mathrm{a}][\mathrm{b}]}$ Chulu Zhou, ${ }^{[\mathrm{a}][\mathrm{b}]}$ and Jianhua Cheng**[a][b]

DOI:

[a] State Key Laboratory of Polymer Physics and Chemistry

Changchun Institute of Applied Chemistry

Chinese Academy of Sciences

No. 5625, Renmin Street, Changchun 130022 (China)

E-Mail: jhcheng@ciac.ac.cn

[b] University of Science and Technology of China

Hefei, Anhui 230029 (China) 
$\begin{array}{ll}\text { 1. Experimental section } & \text { S2 }\end{array}$

2. Selected NMR, GPC, DSC and stress-strain curves spectra $\quad$ S7

$\begin{array}{ll}\text { 3. X-Ray crystallographic studies } & \text { S16 }\end{array}$

$\begin{array}{ll}\text { 4. References } & \text { S17 }\end{array}$

$\begin{array}{lr}\text { 5. Tables of crystal data and structure refinement } & \text { S18 }\end{array}$ 


\section{Experimental Procedures}

\section{General remarks}

All reactions were carried out under a dry and oxygen-free nitrogen atmosphere using Schlenk techniques and a Vigor glovebox. The nitrogen in the glovebox was constantly circulated through a copper/molecular sieves ( $4 \AA$ ) catalyst unit. The oxygen and moisture concentrations in the glovebox atmosphere were monitored by $\mathrm{O}_{2}(\mathrm{GE}) / \mathrm{H}_{2} \mathrm{O}$ (Xentaur) to ensure both were always below $0.1 \mathrm{ppm}$. Toluene, hexane and $\mathrm{Et}_{2} \mathrm{O}$ were purified by use of a Vigor VSPS-5 solvent purification system, and dried over fresh Na chips in the glovebox. Chlorobenzene were purified by use of a Vigor VSPS-5 solvent purification system, and dried over molecular sieves $(4 \AA)$ in the glovebox. THF and $\mathrm{C}_{6} \mathrm{D}_{6}$ were distilled from $\mathrm{Na} / \mathrm{K}$ alloy/benzophenone, degassed by the freeze-pump-thaw method (three times), and dried over fresh $\mathrm{Na}$ chips in the glovebox. $\mathrm{Li}\left(o-\mathrm{CH}_{2} \mathrm{C}_{6} \mathrm{H}_{4}-\mathrm{NMe}_{2}\right),{ }^{[1]}\left[p-\mathrm{CH}_{3}-\mathrm{C}_{6} \mathrm{H}_{3}-\left(o-\mathrm{NMe}_{2}\right)-\right]_{2},{ }^{[2]}$

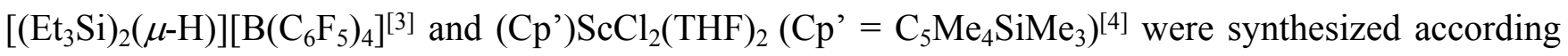
to the published procedures. Styrene and $\mathcal{E}$-caprolactone were dried by stirring with $\mathrm{CaH}_{2}$ for 48 hours, and distilled under reduced pressure prior to polymerization experiments. Other reagents were purchased and used without purification.

\section{NMR measurement}

Samples for NMR spectroscopic measurements were prepared in the glovebox by use of J. Young valve NMR tubes. ${ }^{1} \mathrm{H}$ and ${ }^{13} \mathrm{C}$ NMR spectra were recorded on a Bruker AV400 (FT, $400 \mathrm{MHz}$ for ${ }^{1} \mathrm{H}$; $100 \mathrm{MHz}$ for ${ }^{13} \mathrm{C}$ ) or AV500 (FT, $500 \mathrm{MHz}$ for ${ }^{1} \mathrm{H}$; $125 \mathrm{MHz}$ for ${ }^{13} \mathrm{C}$ ). ${ }^{1} \mathrm{H}$ and ${ }^{13} \mathrm{C}$ NMR spectra of complexes were recorded using TMS as internal standard. The ${ }^{1} \mathrm{H}$ and ${ }^{13} \mathrm{C}$ NMR data of the polymers were obtained in $1,2-\mathrm{C}_{6} \mathrm{D}_{4} \mathrm{Cl}_{2}$ on a Bruker AV400 spectrometer at $100{ }^{\circ} \mathrm{C}$.

\section{DSC measurement}

The DSC measurements were performed on a METTLER TOPEM Diamond Differential Scanning Calorimeter at a heating or cooling rate of $10^{\circ} \mathrm{C} / \mathrm{min}$. Any thermal history difference in the polymers was eliminated by first heating the specimen to $330{ }^{\circ} \mathrm{C}$, cooling at $10{ }^{\circ} \mathrm{C} / \mathrm{min}$ to $0{ }^{\circ} \mathrm{C}$, and then recording the second DSC scan.

\section{GPC measurement}

The molecular weight and molecular weight distribution $\left(M_{\mathrm{w}} / M_{\mathrm{n}}\right)$ of the polymers were determined by gel permeation chromatography (GPC) with a refractive index (RI) detector against polystyrene standards, on TOSOH HLC-8220 GPC (Column: Super HZM-H $\times 3$ ) at $40{ }^{\circ} \mathrm{C}$ using THF as an eluent at 
a flow rate of $0.35 \mathrm{~mL} / \mathrm{min}$, or a PL-GPC 220 type high temperature chromatography equipped with refractive index and viscosimeter detectors, using three PL-gel $10 \mu \mathrm{m}$ Mixed-BLS type columns at 150 ${ }^{\circ} \mathrm{C}$.

\section{Mechanical property study}

The films (around $0.3 \mathrm{~mm}$ thick) for tensile test were prepared by casting from a $o$-DCB solution (3 $\mathrm{wt} \%$ ) of a sample. A polymer sample was first dissolved in $o$-DCB at $120{ }^{\circ} \mathrm{C}$ for $2 \mathrm{~h}$ and then casted at $80{ }^{\circ} \mathrm{C}$ in $24 \mathrm{~h}$. The resulting film was dried under vacuum for one week at $60{ }^{\circ} \mathrm{C}$ to completely remove any residual solvent. Samples then were cut into specimens of 4-7 $\mathrm{mm}$ long $\times 0.3 \mathrm{~mm}$ wide using a dogbone die. Uniaxial tensile testing experiments were performed at room temperature on a Lnstron1121 Tensile Instrument molded according to GB/T1447 at a crosshead speed of $10 \mathrm{~mm} / \mathrm{min}$. At least three tensile measurements were performed for each sample.

\section{Synthesis of $\left[\left(\mathrm{Cp}^{\prime}\right) \mathrm{Sc}\left(o-\mathrm{CH}_{2} \mathrm{C}_{6} \mathrm{H}_{4}-\mathrm{NMe} 2\right)(\mathrm{THF}) \mathrm{Cl}\right](1)$}

In the glovebox, $\mathrm{Li}\left(o-\mathrm{CH}_{2} \mathrm{C}_{6} \mathrm{H}_{4}-\mathrm{NMe}_{2}\right)(141 \mathrm{mg}, 1 \mathrm{mmol})$ in $10 \mathrm{~mL}$ THF solution was added dropwise to a stirred solution of $\left(\mathrm{C}_{5} \mathrm{Me}_{4} \mathrm{SiMe}_{3}\right) \mathrm{ScCl}_{2}(\mathrm{THF})_{2}(453 \mathrm{mg}, 1 \mathrm{mmol})$ in THF $(5 \mathrm{~mL})$. The resulting slurry was stirred at room temperature for $12 \mathrm{~h}$. All volatiles were removed under vacuum and the solid was extracted with hexane $(2 \times 5 \mathrm{~mL})$. The pale-yellow filtrate was concentrated to $3 \mathrm{~mL}$, and kept at $-30{ }^{\circ} \mathrm{C}$ to give 1 (394 mg, $0.82 \mathrm{mmol}, 82 \%$ yields) as colorless crystals. Single crystals of 1 suitable for X-ray analysis, were grown from hexane at $-30{ }^{\circ} \mathrm{C} .{ }^{1} \mathrm{H}$ NMR $\left(500 \mathrm{MHz}, \mathrm{C}_{6} \mathrm{D}_{6}, 25^{\circ} \mathrm{C}\right) \delta=$ 7.42 (dd, $J=1.5 \mathrm{~Hz}, 1 \mathrm{H}$, aryl), 7.28 (d, 1H, aryl), 7.20 (d, $J=1.5 \mathrm{~Hz}, 1 \mathrm{H}$, aryl), 7.16 (br, 1H, aryl), 3.63 (m, 4H, THF), $2.53\left(\mathrm{~s}, 6 \mathrm{H}, \mathrm{C}_{5} \mathrm{Me}_{4}\right), 2.26\left(\mathrm{~s}, 6 \mathrm{H}, \mathrm{NMe}_{2}\right), 1.93\left(\mathrm{~s}, 4 \mathrm{H}, \mathrm{CH}_{2}\right), 1.59\left(\mathrm{~s}, 6 \mathrm{H}, \mathrm{C}_{5} \mathrm{Me}_{4}\right), 1.40(\mathrm{~m}$, $4 \mathrm{H}, \mathrm{THF}), 0.54$ (s, 9H, $\left.\mathrm{SiMe}_{3}\right) \cdot{ }^{13} \mathrm{C}\left\{{ }^{1} \mathrm{H}\right\}$ NMR $\left(126 \mathrm{MHz}, \mathrm{C}_{6} \mathrm{D}_{6}, 25^{\circ} \mathrm{C}\right) \delta=142.19,139.71,134.36$, 129.21, 129.02, 124.08, 123.98, 120.28, 114.32 (aromatics and Cp ring carbons), 66.81 (THF), 51.21 $\left(\mathrm{CH}_{2}\right), 44.20$ (br, $\left.\mathrm{NMe}_{2}\right), 23.67$ (THF), 13.28, $9.28\left(\mathrm{C}_{5} \mathrm{Me}_{4}\right), 0.22\left(\mathrm{SiMe}_{3}\right)$. Anal. Calcd. For (1) $\mathrm{C}_{25} \mathrm{H}_{41} \mathrm{CINOScSi}$ (480.10): C, 62.54; H, 8.61; Found: C 62.80; H 8.82.

\section{Synthesis of $\left[\left(\mathrm{Cp}^{\prime}\right) \mathrm{Sc}(\mathrm{THF}) \mathrm{Cl}\right]_{2}\left[p-\left(\mathrm{CH}_{2} \mathrm{C}_{6} \mathrm{H}_{3}\left(o-\mathrm{NMe}_{2}\right)-\right)_{2}\right](2)$}

$n$-BuLi ( $8 \mathrm{~mL}$ of $2.5 \mathrm{M}$ solution in hexane, $20 \mathrm{mmol})$ was added dropwise to a stirred $\mathrm{Et}_{2} \mathrm{O}(100$ $\mathrm{mL})$ solution of $\left[p-\mathrm{CH}_{3}-\mathrm{C}_{6} \mathrm{H}_{3}-\left(o-\mathrm{NMe}_{2}\right)-\right]_{2}(2.1 \mathrm{~g}, 7.8 \mathrm{mmol})$ in a Schlenk-Flask. This Schlenk-Flask was heated at $70{ }^{\circ} \mathrm{C}$ for $12 \mathrm{~h}$ and returned to the glovebox. The reaction mixture was filtered and the residue was washed with ether and hexane to afford dilithium bis(aminobenzyl) [Li- $p$ - $\mathrm{CH}_{2} \mathrm{C}_{6} \mathrm{H}_{3}(o$ $\left.\left.\mathrm{NMe}_{2}\right)-\right]_{2}$ as a yellow solid product (2a) $(1.7 \mathrm{~g}, 6.2 \mathrm{mmol}, 80 \%$ yield). The purity of $\mathbf{2 a}$ was monitored by the reaction with $\mathrm{MeI}$. 
In a glovebox, 2a (280mg, $1 \mathrm{mmol})$ in $10 \mathrm{~mL}$ THF solution was added dropwise to a stirred solution of $\left(\mathrm{C}_{5} \mathrm{Me}_{4} \mathrm{SiMe}_{3}\right) \mathrm{ScCl}_{2}(\mathrm{THF})_{2}(906 \mathrm{mg}, 2 \mathrm{mmol})$ in THF $(5 \mathrm{~mL})$. The resulting slurry was stirred at room temperature for $12 \mathrm{~h}$. All volatiles were removed under vacuum and the solid was extracted with hexane $(2 \times 5 \mathrm{~mL})$. The pale-yellow filtrate was concentrated to $3 \mathrm{~mL}$, and kept at $-30^{\circ} \mathrm{C}$ to give $2(720$ $\mathrm{mg}, 0.76 \mathrm{mmol}, 76 \%$ yields) as colorless crystals. Single crystals of 2 suitable for X-ray analysis, were grown from toluene/hexane at $-30{ }^{\circ} \mathrm{C} .{ }^{1} \mathrm{H}$ NMR $\left(500 \mathrm{MHz}, \mathrm{C}_{6} \mathrm{D}_{6}, 25^{\circ} \mathrm{C}\right): \delta=7.06(\mathrm{t}, J=2 \mathrm{~Hz}, 2 \mathrm{H}$, aryl), $6.87\left(\mathrm{t}, \mathrm{J}=2 \mathrm{~Hz}, 2 \mathrm{H}\right.$, aryl), 6.79 (d, $J=2.5 \mathrm{~Hz}, 2 \mathrm{H}$, aryl), 3.63 (br, 8H, THF), $2.62\left(\mathrm{~s}, 12 \mathrm{H}, \mathrm{C}_{5} \mathrm{Me}_{4}\right)$, $2.25\left(\mathrm{~s}, 12 \mathrm{H}, \mathrm{NMe}_{2}\right), 1.85\left(\mathrm{~s}, 4 \mathrm{H}, \mathrm{CH}_{2}\right), 1.65$ (s, 12H, C $\left.\mathrm{Me}_{4}\right), 1.40$ (br, 8H, THF), 0.58 (s, 18H, $\mathrm{SiMe}_{3}$ ). ${ }^{13} \mathrm{C}\left\{{ }^{1} \mathrm{H}\right\}$ NMR $\left(126 \mathrm{MHz}, \mathrm{C}_{6} \mathrm{D}_{6}, 25^{\circ} \mathrm{C}\right) \delta=144.51,142.20,127.92,127.69,124.58,123.25,119.60$, 118.36, 115.52 (aromatics and Cp ring carbons), 66.70 (THF), $51.72\left(\mathrm{CH}_{2}\right), 44.31$ (br, $\left.\mathrm{NMe}_{2}\right)$, 23.22(THF), 12.99, $9.20\left(\mathrm{C}_{5} M e_{4}\right), 0.21\left(\mathrm{SiMe}_{3}\right)$. Anal. Calcd. For (2) $\mathrm{C}_{50} \mathrm{H}_{80} \mathrm{Cl}_{2} \mathrm{~N}_{2} \mathrm{O}_{2} \mathrm{Sc}_{2} \mathrm{Si}_{2}(958.16): \mathrm{C}$, 62.68; H, 8.42; Found: C 62.98; H 8.71.

\section{General styrene polymerization experiments}

A typical procedure for the syndiospecific polymerization of styrene (Table 1, run 1): In a glove box, $\left[\left(\mathrm{Et}_{3} \mathrm{Si}\right)_{2}(\mu-\mathrm{H})\right]\left[\mathrm{B}\left(\mathrm{C}_{6} \mathrm{~F}_{5}\right)_{4}\right](19 \mathrm{mg}, 21 \mu \mathrm{mol})$ in $4 \mathrm{~mL}$ chlorobenzene solution was added to $\left[\left(\mathrm{Cp}^{\prime}\right) \mathrm{Sc}\left(o-\mathrm{CH}_{2} \mathrm{C}_{6} \mathrm{H}_{4}-\mathrm{NMe}_{2}\right)(\mathrm{THF}) \mathrm{Cl}\right](\mathbf{1})(10 \mathrm{mg}, 21 \mu \mathrm{mol})$ in chlorobenzene $(2 \mathrm{~mL})$ at $-30{ }^{\circ} \mathrm{C}$. After the mixture was stirred at room temperature for 15 minutes, $0.21 \mathrm{~g}(2.1 \mathrm{mmol})$ of styrene was added under vigorous stirring. After 1 minutes, ethanol $(2 \mathrm{~mL})$ was added to terminate the polymerization. The mixture was poured into a large quantity of ethanol $(400 \mathrm{~mL})$ containing a small amount of hydrochloric acid to precipitate the polymer product. The white polymer powder was collected by filtration, and dried under vacuum at $60^{\circ} \mathrm{C}$ to a constant weight $(0.21 \mathrm{~g},>99 \%)$.

\section{General \&-caprolactone polymerization experiments}

A typical procedure for the polymerization of $\varepsilon$-caprolactone (Table 1, run 10): In a glove box, $\left[\left(\mathrm{Et}_{3} \mathrm{Si}\right)_{2}(\mu-\mathrm{H})\right]\left[\mathrm{B}\left(\mathrm{C}_{6} \mathrm{~F}_{5}\right)_{4}\right](39 \mathrm{mg}, 42 \mu \mathrm{mol})$ in $4 \mathrm{~mL}$ chlorobenzene solution was added to $\left[\left(\mathrm{Cp}^{\prime}\right) \mathrm{Sc}(\mathrm{THF}) \mathrm{Cl}\right]_{2}\left[p-\left(\mathrm{CH}_{2} \mathrm{C}_{6} \mathrm{H}_{3}\left(o-\mathrm{NMe}_{2}\right)-\right)_{2}\right](2)(10 \mathrm{mg}, 21 \mu \mathrm{mol})$ in chlorobenzene $(2 \mathrm{~mL})$ at $-30{ }^{\circ} \mathrm{C}$. After the mixture was stirred at room temperature for 15 minutes, $0.24 \mathrm{~g}(2.1 \mathrm{mmol})$ of $\varepsilon$-caprolactone was added under vigorous stirring. After 10 minutes, ethanol $(2 \mathrm{~mL})$ was added to terminate the polymerization. The mixture was poured into a large quantity of ethanol $(400 \mathrm{~mL})$ containing a small amount of hydrochloric acid to precipitate the polymer product. The white polymer powder was collected by filtration, and dried under vacuum at $60^{\circ} \mathrm{C}$ to a constant weight $(0.24 \mathrm{~g},>99 \%)$. 


\section{General styrene and \&-caprolactone block copolymerization experiments}

A typical procedure for the block copolymerization of styrene and $\varepsilon$-caprolactone (Table 2, run 4): In a glove box, $\left[\left(\mathrm{Et}_{3} \mathrm{Si}\right)_{2}(\mu-\mathrm{H})\right]\left[\mathrm{B}\left(\mathrm{C}_{6} \mathrm{~F}_{5}\right)_{4}\right](78 \mathrm{mg}, 84 \mu \mathrm{mol})$ in $4 \mathrm{~mL}$ chlorobenzene solution was added to $\left[\left(\mathrm{Cp}^{\prime}\right) \mathrm{Sc}(\mathrm{THF}) \mathrm{Cl}\right]_{2}\left[p-\left(\mathrm{CH}_{2} \mathrm{C}_{6} \mathrm{H}_{3}\left(o-\mathrm{NMe}_{2}\right)-\right)_{2}\right](2)(40 \mathrm{mg}, 42 \mu \mathrm{mol})$ in chlorobenzene $(2 \mathrm{~mL})$ at $30{ }^{\circ} \mathrm{C}$. After the mixture was stirred at room temperature for 15 minutes, $0.42 \mathrm{~g} \mathrm{(4.2} \mathrm{mmol)} \mathrm{styrene} \mathrm{was}$ added under vigorous stirring. Ten minutes later, $0.96 \mathrm{~g}(8.4 \mathrm{mmol}) \varepsilon$-caprolactone in $20 \mathrm{~mL}$ chlorobenzene was added. The mixture was then stirred for 60 minutes. The polymerization was terminated by addition of $10 \mathrm{~mL}$ of ethanol, and the mixture was poured into a large quantity of ethanol $(400 \mathrm{~mL})$ containing a small amount of hydrochloric acid to precipitate the polymer product. To remove small amount of PCL homopolymer, the polymer powder was poured into $30 \mathrm{ml}$ of acetone and stirred for 30 minutes. The polymer was collected by filtration and washed with acetone several times, and dried under vacuum at $60{ }^{\circ} \mathrm{C}$ to a constant weight. 
2 Selected NMR, GPC, DSC and stress-strain curves spectra

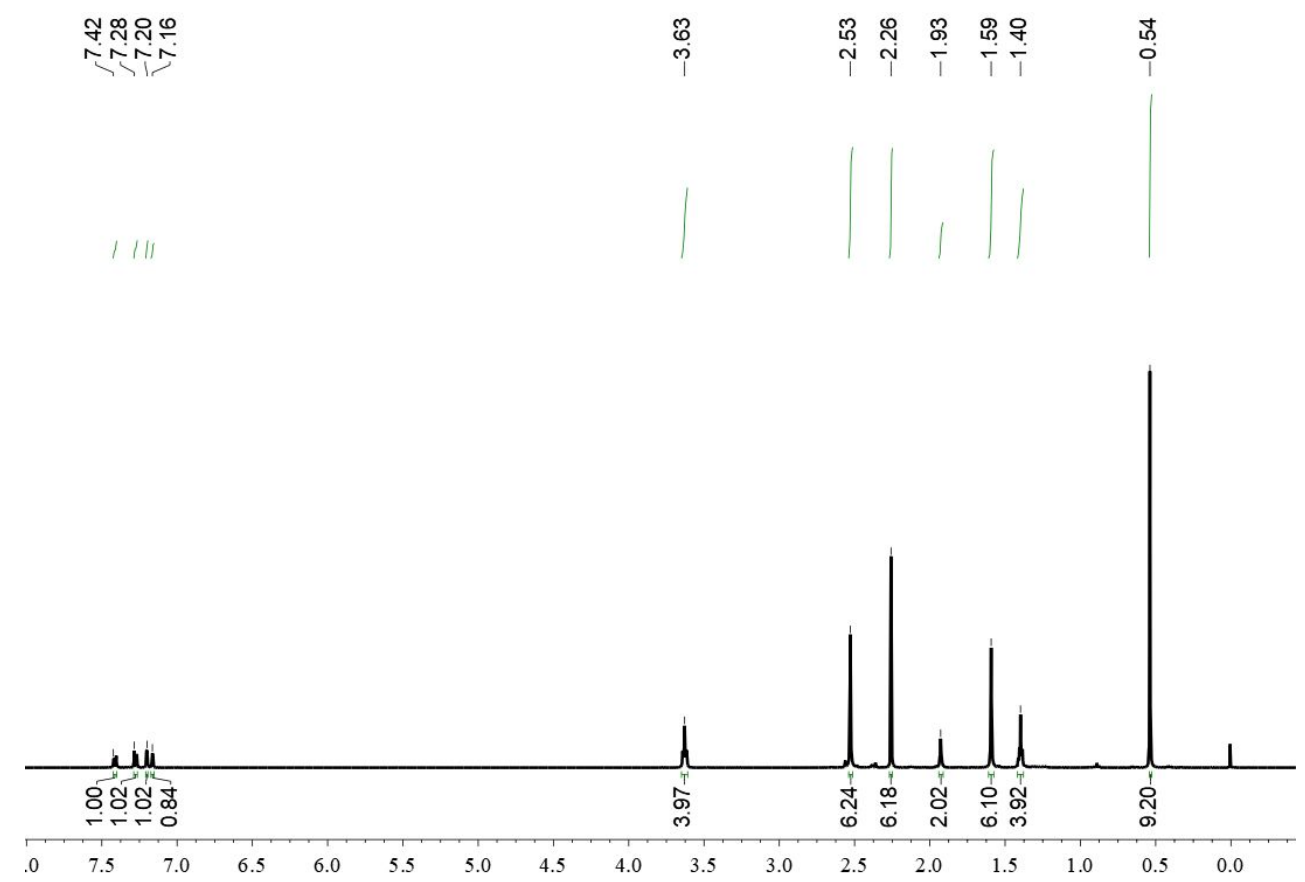

Figure S1. ${ }^{1} \mathrm{H}$ NMR spectrum $(500 \mathrm{MHz})$ of complex 1 in $\mathrm{C}_{6} \mathrm{D}_{6}$ at $25{ }^{\circ} \mathrm{C}$.

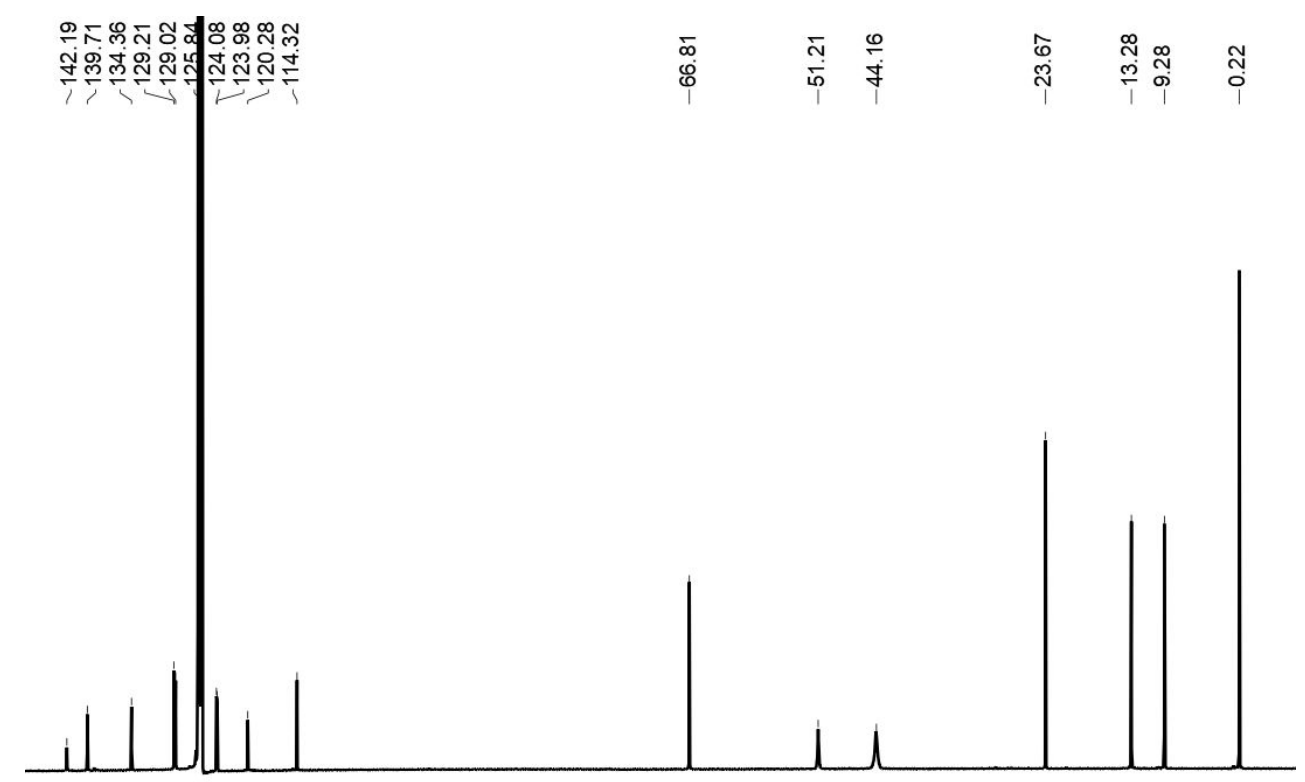

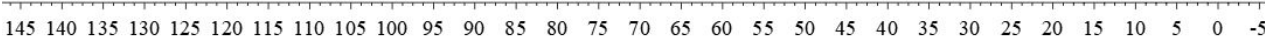

Figure S2. ${ }^{13} \mathrm{C}\left\{{ }^{1} \mathrm{H}\right\}$ NMR spectrum $(126 \mathrm{MHz})$ of complex 1 in $\mathrm{C}_{6} \mathrm{D}_{6}$ at $25{ }^{\circ} \mathrm{C}$. 


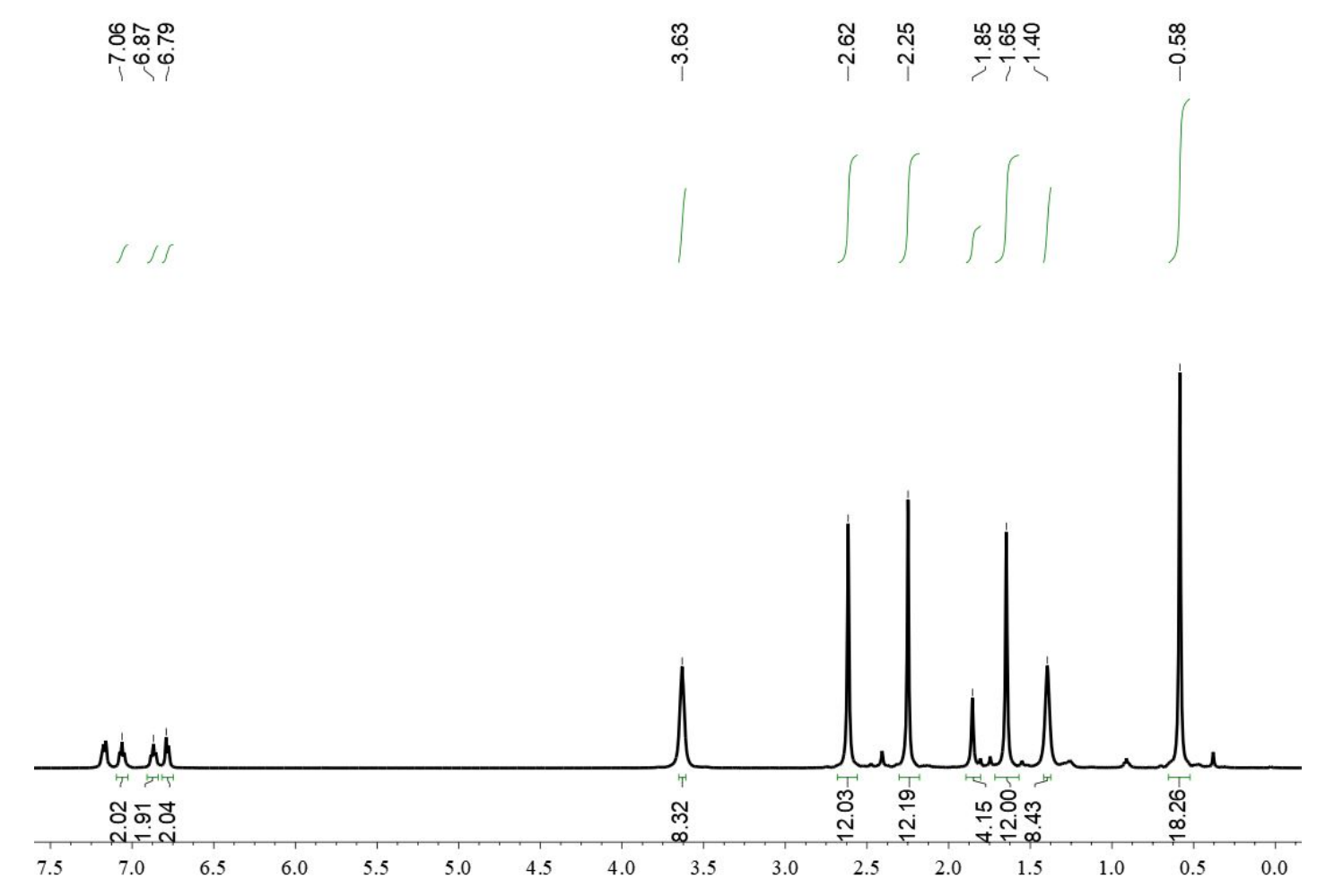

Figure S3. ${ }^{1} \mathrm{H}$ NMR spectrum $(500 \mathrm{MHz})$ of complex 2 in $\mathrm{C}_{6} \mathrm{D}_{6}$ at $25{ }^{\circ} \mathrm{C}$.

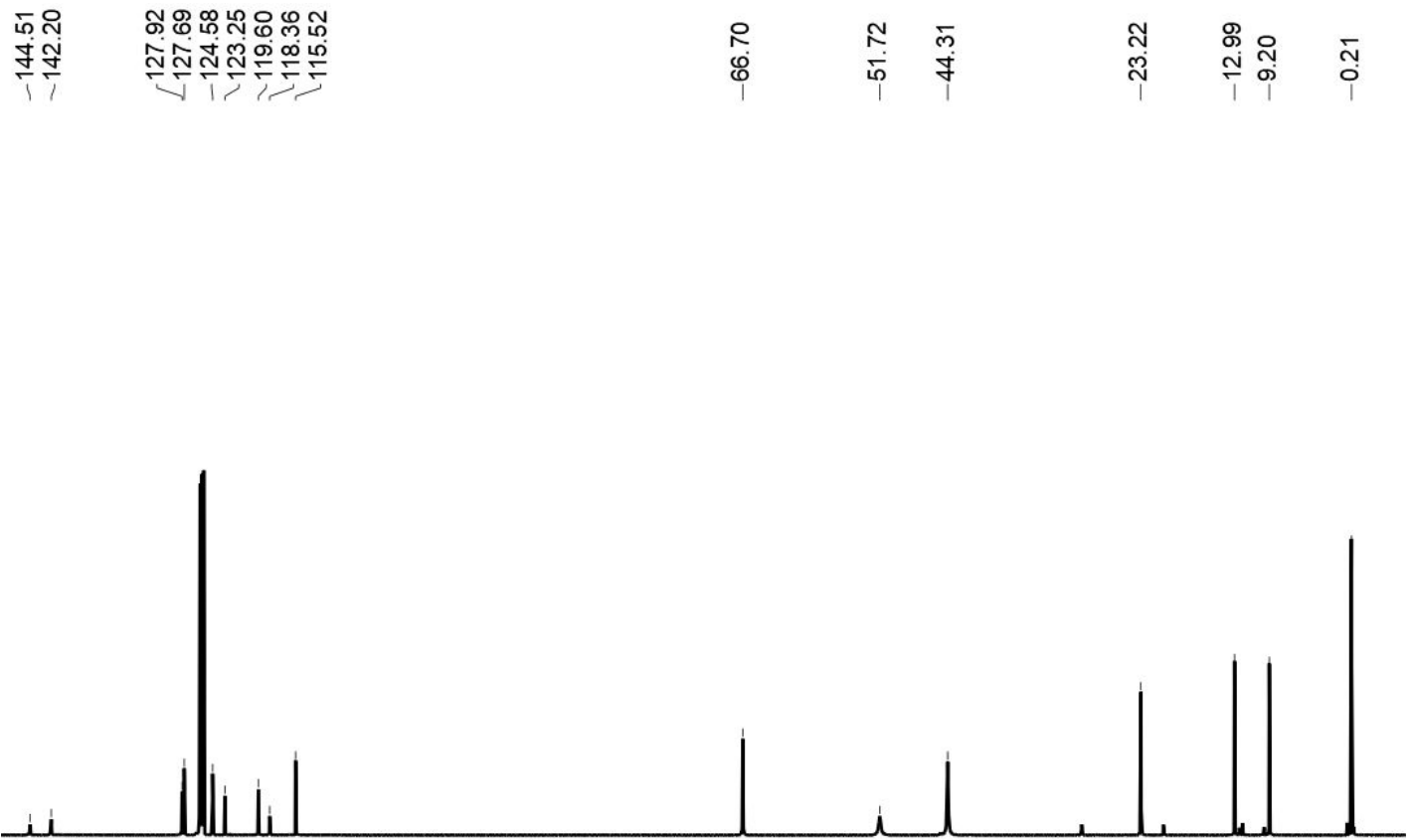

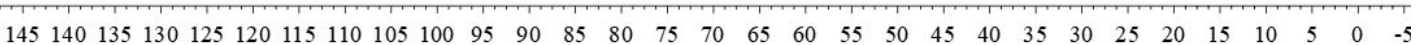

Figure S4. ${ }^{13} \mathrm{C}\left\{{ }^{1} \mathrm{H}\right\}$ NMR spectrum $(126 \mathrm{MHz})$ of complex 2 in $\mathrm{C}_{6} \mathrm{D}_{6}$ at $25{ }^{\circ} \mathrm{C}$. 


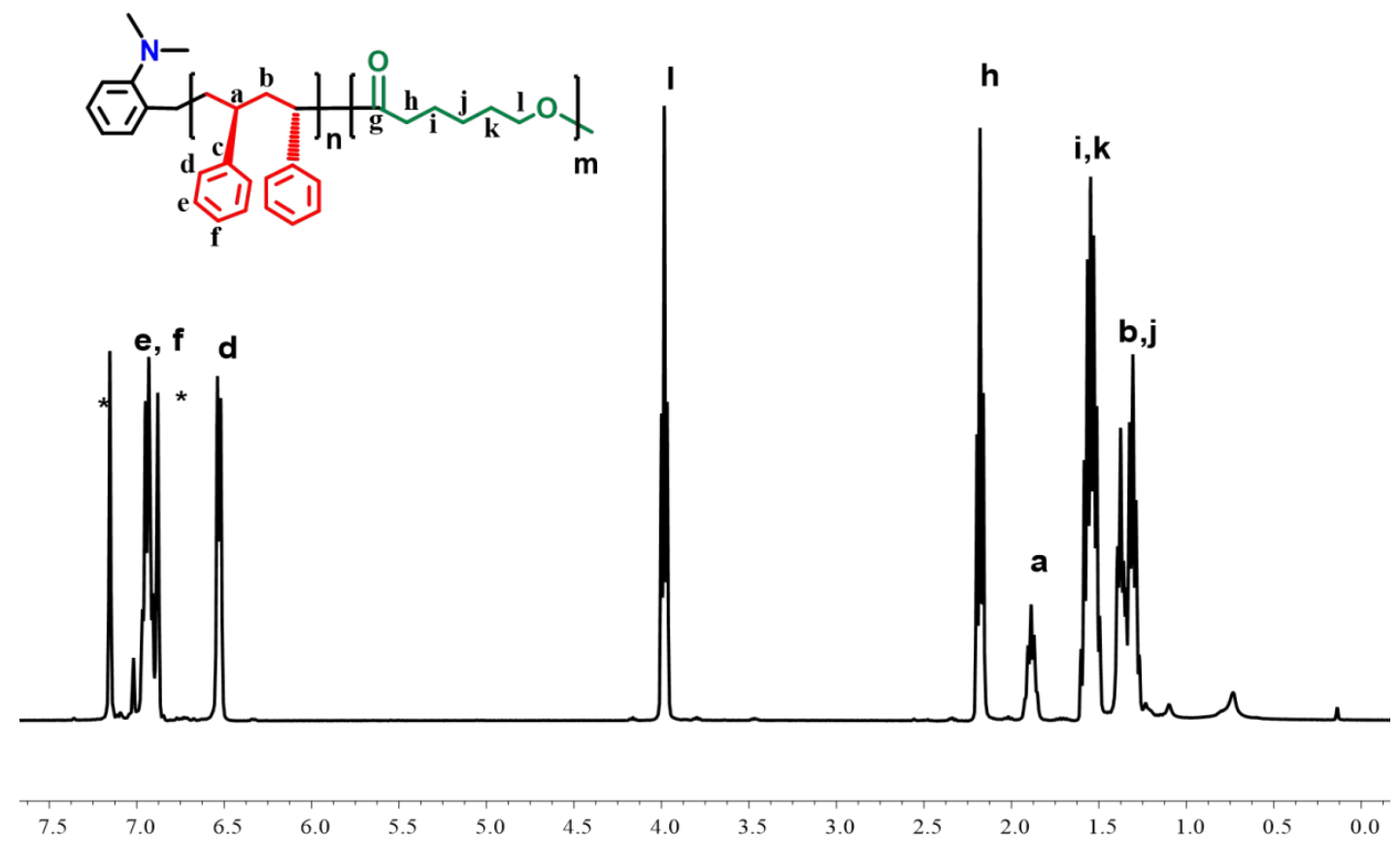

Figure S5. ${ }^{1} \mathrm{H}$ NMR spectrum $(400 \mathrm{MHz})$ of $s$ PS- $b$-PCL diblock copolymer containing $41 \mathrm{~mol} \%$ of sPS (Table 2: Run 1).

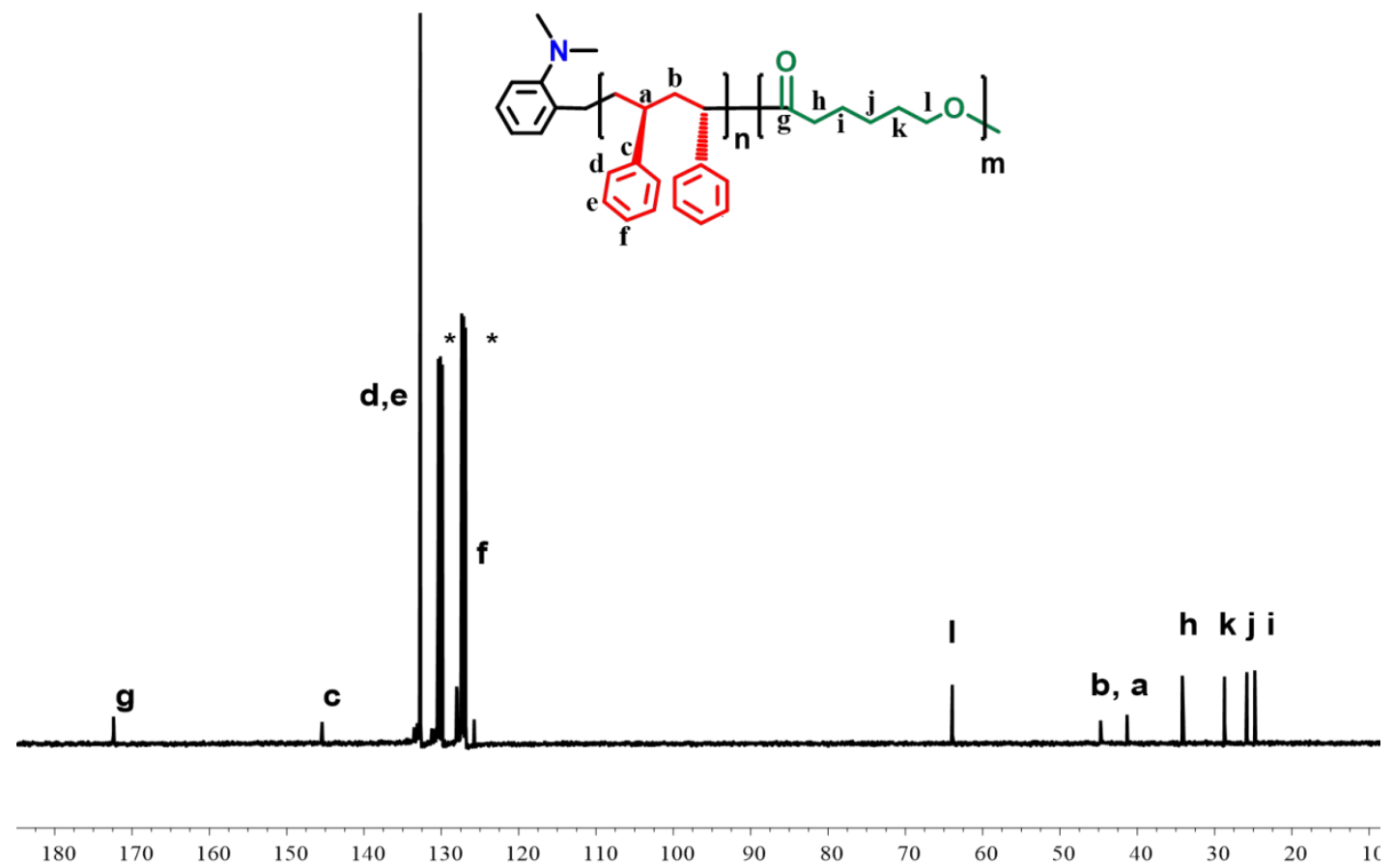

Figure S6. ${ }^{13} \mathrm{C}\left\{{ }^{1} \mathrm{H}\right\}$ NMR spectrum (400 MHz) of $s$ PS- $b$-PCL diblock copolymer containing $41 \mathrm{~mol} \%$ of $s$ PS (Table 2: Run 1). 

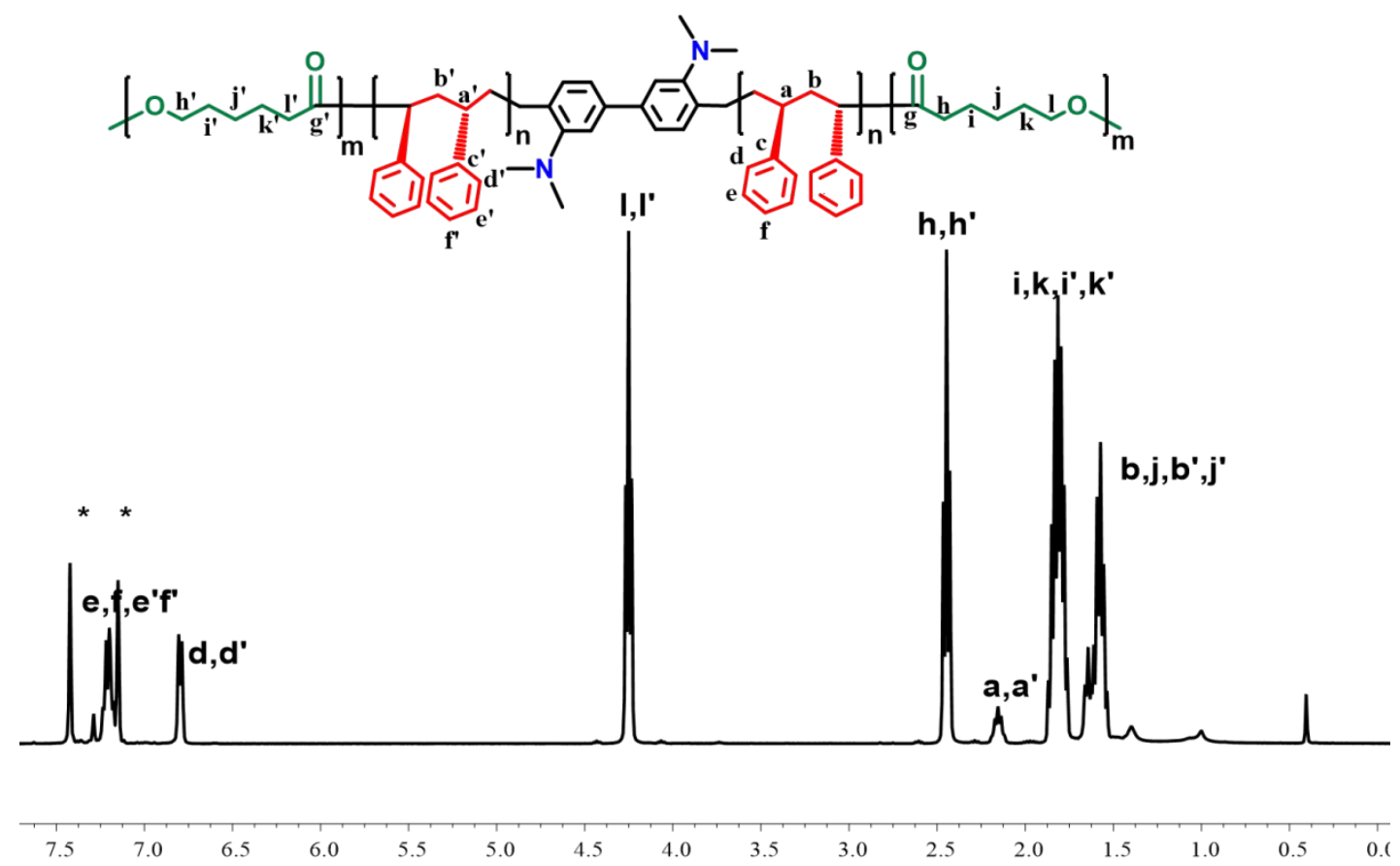

Figure S7. ${ }^{1} \mathrm{H}$ NMR spectrum (400 MHz) of PCL- $b$-sPS- $b$-PCL triblock copolymer containing 22 mol \% of $s$ PS (Table 2: Run 6).
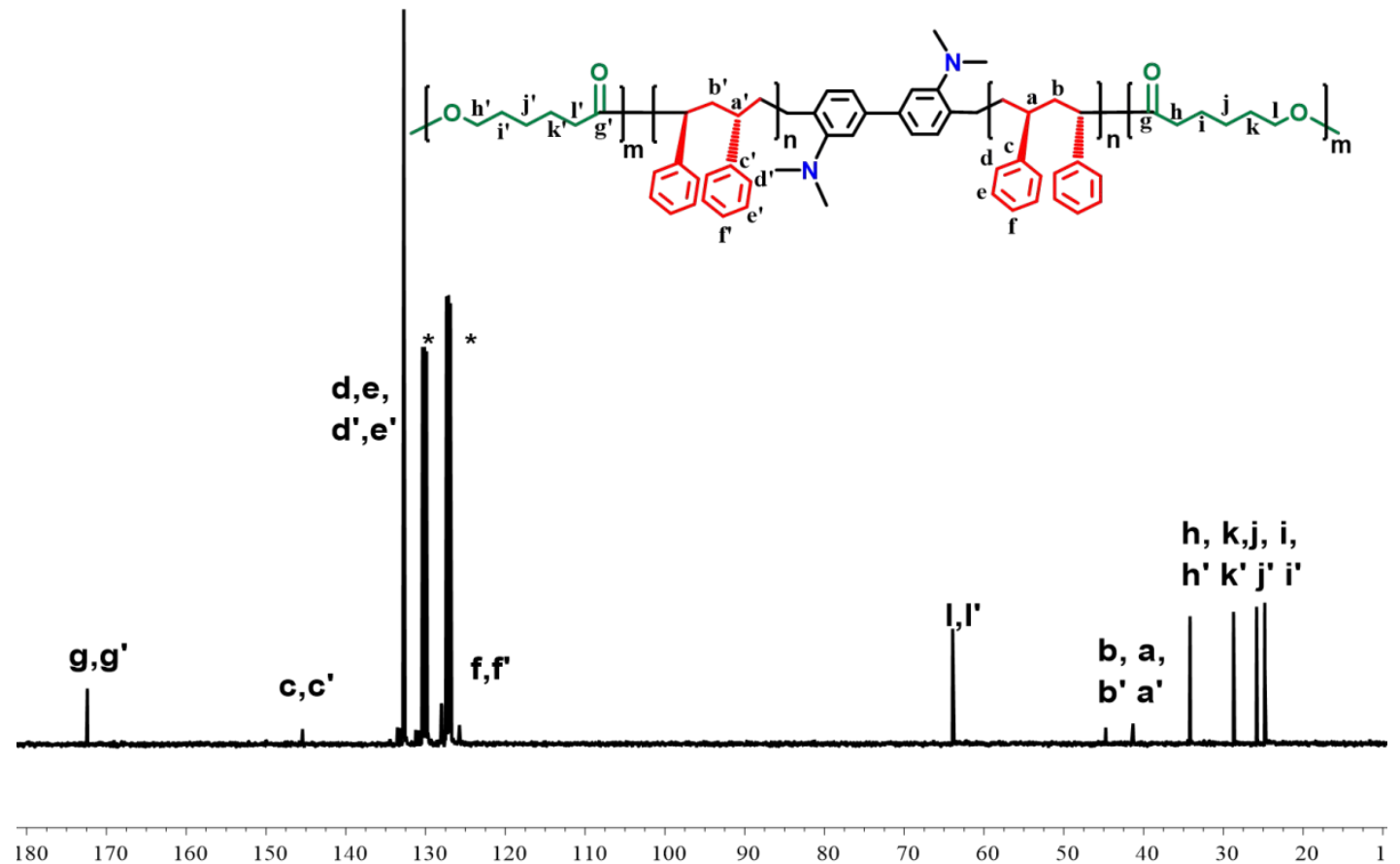

Figure S8. ${ }^{13} \mathrm{C}\left\{{ }^{1} \mathrm{H}\right\}$ NMR spectrum $(400 \mathrm{MHz})$ of PCL- $b$-sPS- $b$-PCL triblock copolymer containing 22 mol \% of $s$ PS (Table 2: Run 6). 


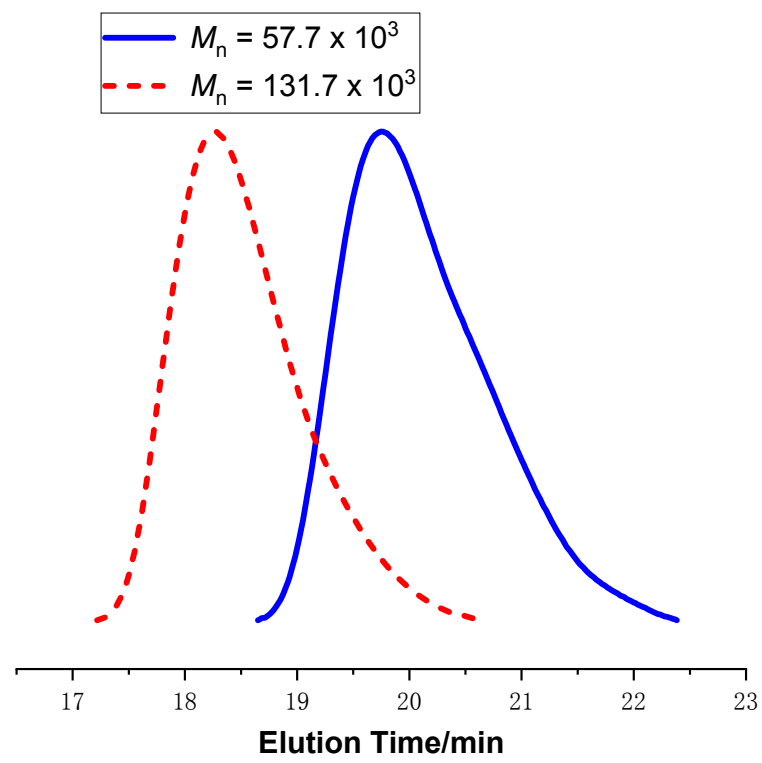

Figure S9. GPC traces of the $s$ PS synthesized by complex $\mathbf{1} /\left[\left(\mathrm{Et}_{3} \mathrm{Si}\right)_{2}(\mu-\mathrm{H})\right]\left[\mathrm{B}\left(\mathrm{C}_{6} \mathrm{~F}_{5}\right)_{4}\right]\left(\right.$ Run $\mathbf{1}\left(M_{\mathrm{n}}=\right.$ $\left.57.7 \times 10^{3}, M_{\mathrm{w}} / M_{\mathrm{n}}=2.25\right)$; and Run $2\left(M_{\mathrm{n}}=131.7 \times 10^{3}, M_{\mathrm{w}} / M_{\mathrm{n}}=2.06\right)$ in Table 1).

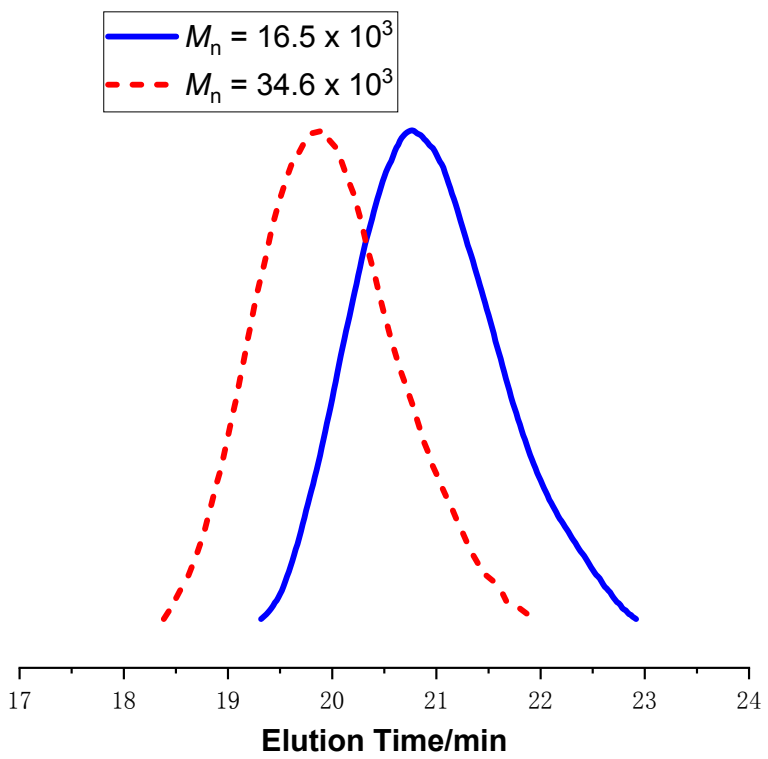

Figure S10. GPC traces of the PCL synthesized by $2 / 2 \times\left[\left(\mathrm{Et}_{3} \mathrm{Si}\right)_{2}(\mu-\mathrm{H})\right]\left[\mathrm{B}\left(\mathrm{C}_{6} \mathrm{~F}_{5}\right)_{4}\right](\mathrm{Run} 10$ $\left(M_{\mathrm{n}}=16.5 \times 10^{3}, M_{\mathrm{w}} / M_{\mathrm{n}}=1.34\right)$; Run $11\left(M n=34.6 \times 10^{3}, M_{\mathrm{w}} / M_{\mathrm{n}}=1.52\right)$ in Table 1). 


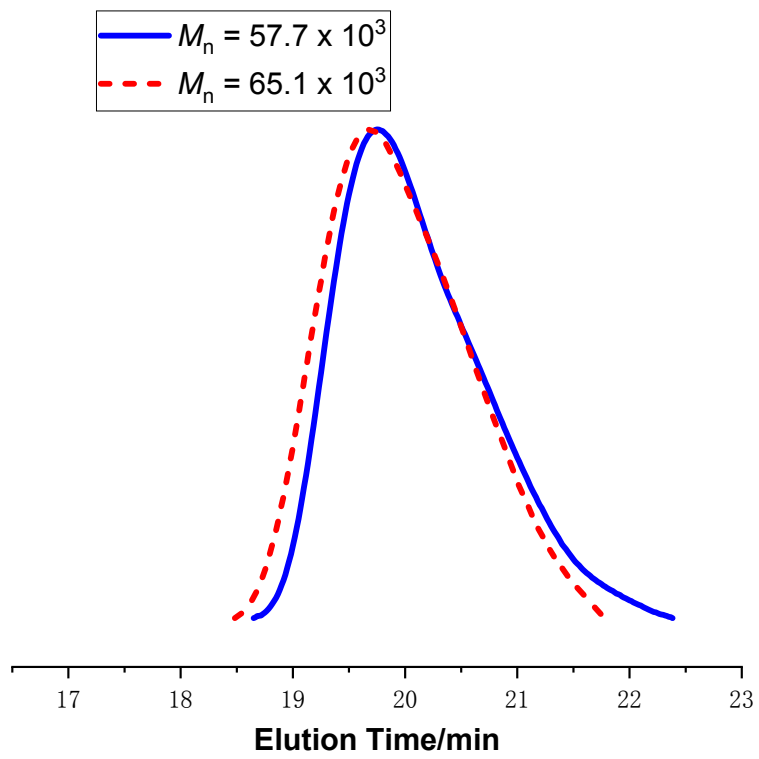

Figure S11. GPC traces of the sPS synthesized by $1 /\left[\left(\mathrm{Et}_{3} \mathrm{Si}\right)_{2}(\mu-\mathrm{H})\right]\left[\mathrm{B}\left(\mathrm{C}_{6} \mathrm{~F}_{5}\right)_{4}\right]\left(\right.$ run $1 M_{\mathrm{n}}=57.7 \times 10^{3}$, $\left.M_{\mathrm{w}} / M_{\mathrm{n}}=2.25\right)$ and by $2 / 2 \times\left[\left(\mathrm{Et}_{3} \mathrm{Si}\right)_{2}(\mu-\mathrm{H})\right]\left[\mathrm{B}\left(\mathrm{C}_{6} \mathrm{~F}_{5}\right)_{4}\right]\left(\right.$ run $\left.2 M_{\mathrm{n}}=65.1 \times 10^{3}, M_{\mathrm{w}} / M_{\mathrm{n}}=2.54\right)$ in Table 1).

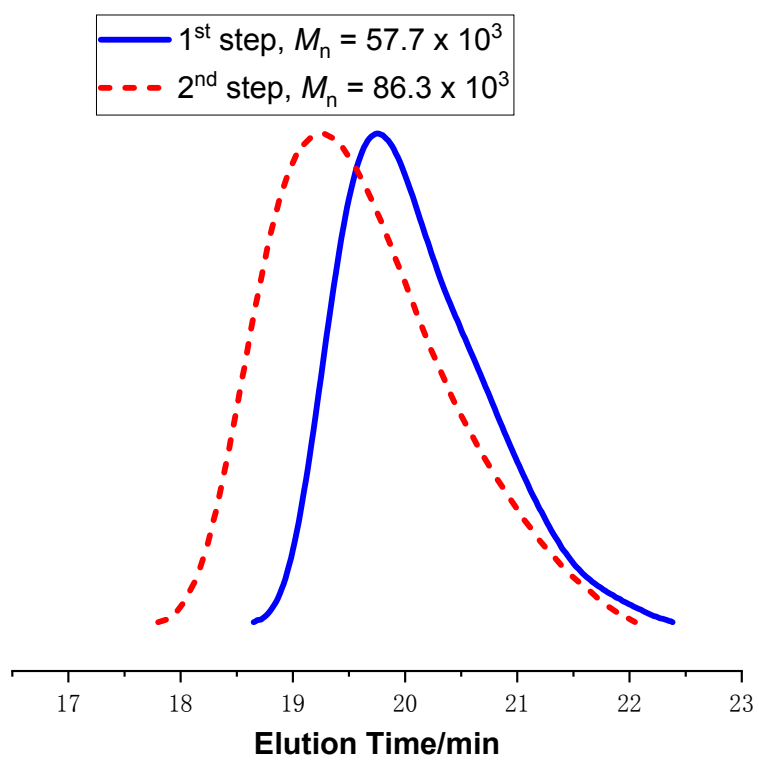

Figure S12. GPC traces of sequential styrene-CL block copolymerization by $\mathbf{1} /\left[\left(\mathrm{Et}_{3} \mathrm{Si}\right)_{2}(\mu-\mathrm{H})\right]-\left[\mathrm{B}\left(\mathrm{C}_{6} \mathrm{~F}_{5}\right)_{4}\right]$ (Table 2, run 1, first step, sPs, $M_{n}=57.7 \times 10^{3}, M_{w} / M_{n}=2.25$; second step, $s$ Ps- $b$-PCL, $M_{n}=86.3 \times 10^{3}$, $\left.M_{\mathrm{w}} / M_{\mathrm{n}}=1.64\right)$. 


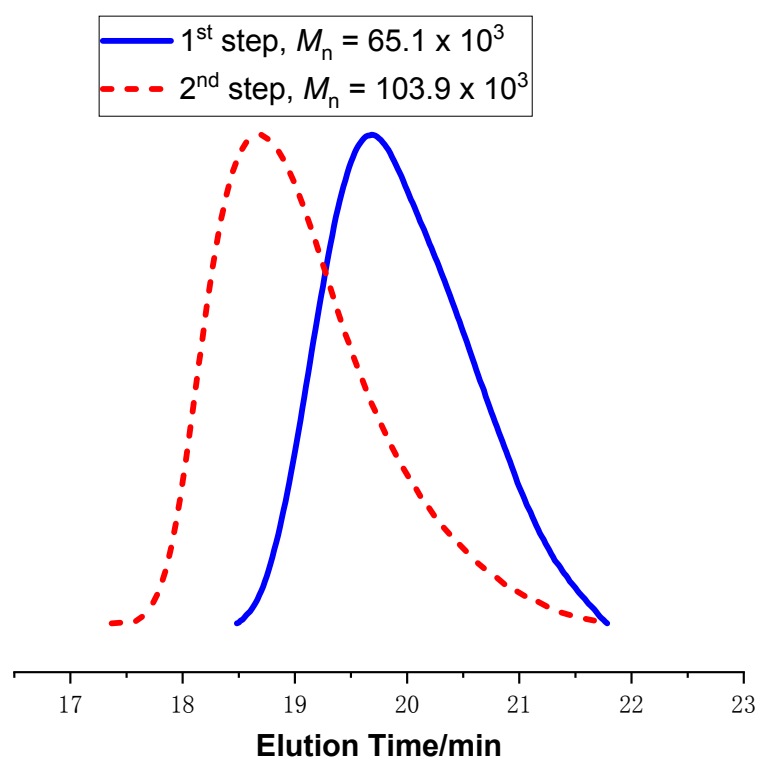

Figure S13. GPC traces of sequential styrene-CL block copolymerization by $2 / 2 \times\left[\left(\mathrm{Et}_{3} \mathrm{Si}\right)_{2}(\mu-\right.$ $\mathrm{H})]\left[\mathrm{B}\left(\mathrm{C}_{6} \mathrm{~F}_{5}\right)_{4}\right]$ (Table 2, run 1, first step, sPs, $M_{\mathrm{n}}=65.1 \times 10^{3}, M_{\mathrm{w}} / M_{\mathrm{n}}=2.54$; second step, PCL- $b$-sPs-bPCL, $\left.M_{\mathrm{n}}=103.9 \times 10^{3}, M_{\mathrm{w}} / M_{\mathrm{n}}=1.76\right)$.

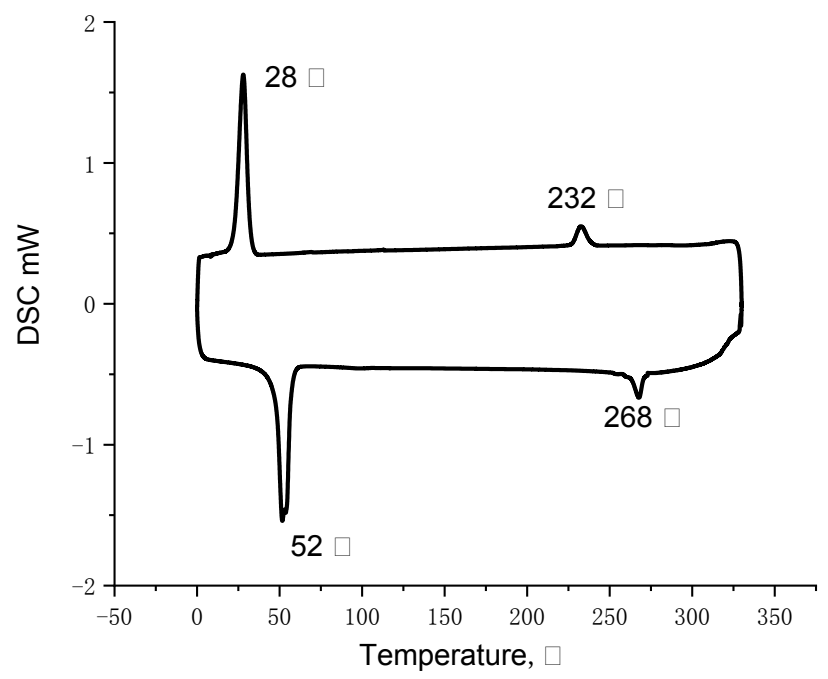

Figure S14. DSC curve of sPS-b-PCL diblock copolymer containing 33 mol\% of sPS (Run 2 in Table 2). 


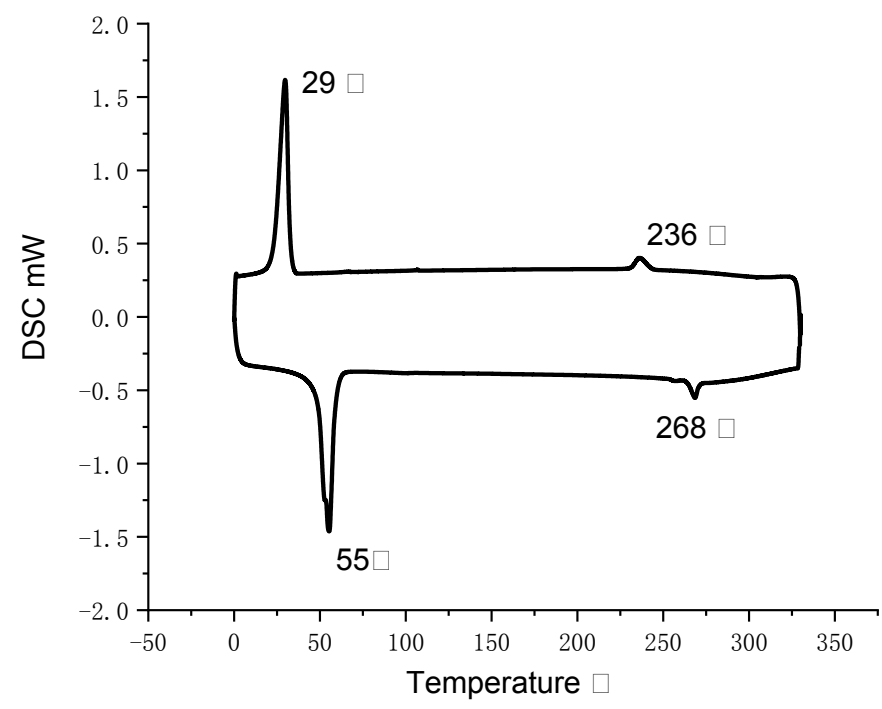

Figure S15. DSC curve of PCL- $b$-sPS-b-PCL triblock copolymer containing 27 mol\% of $s$ PS (Run 5 in Table 2).

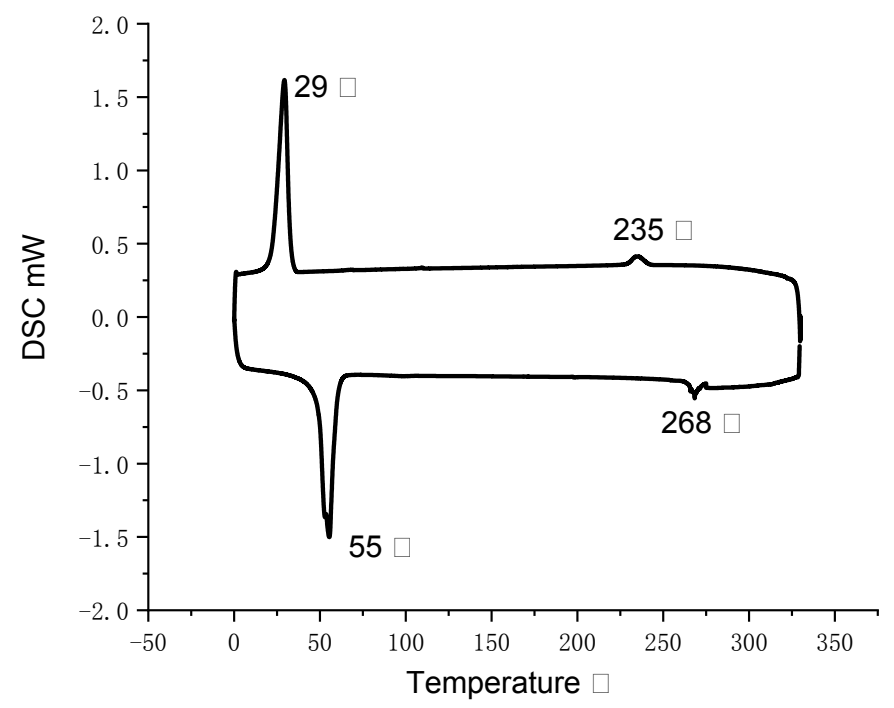

Figure S16. DSC curve of PCL- $b$-sPS- $b$-PCL triblock copolymer containing 22 mol $\%$ of $s$ PS (Run 6 in Table 2). 


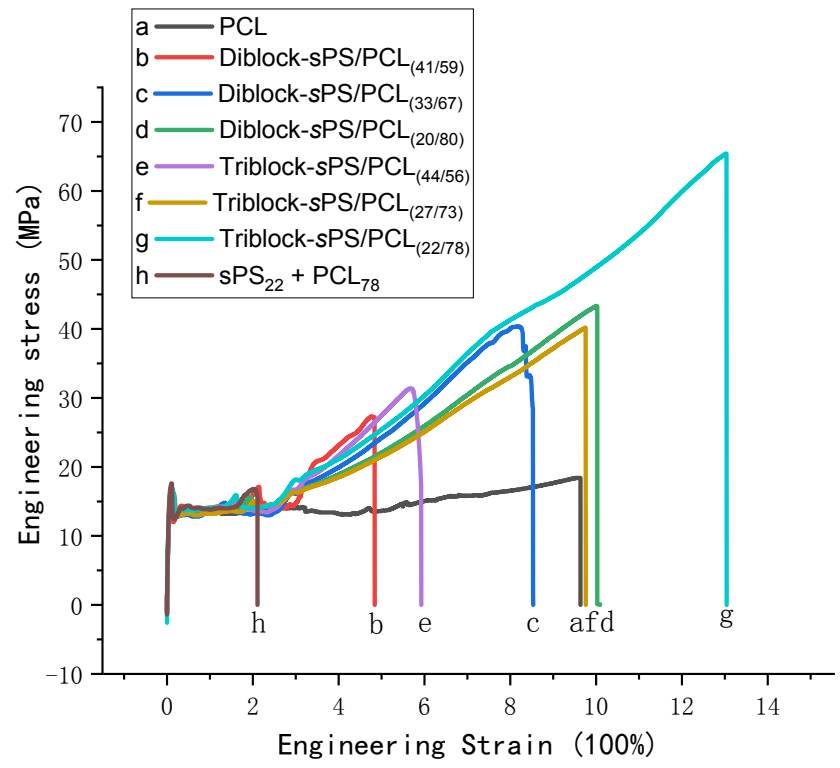

Figure S17 Engineering stress-strain curves of (a) sPS/PCL blend(run 9 in Table 3); (h) PCL (run 2 in Table 3); (b-d) $s$ PS- $b$-PCL diblock copolymers (runs 3-5 in Table 3); (e-g) $s$ PS-b-PCL triiblock copolymers (runs 6-8 in Table 3). 


\section{X-ray Crystallographic Studies}

Single crystals suitable for X-Ray analysis were obtained as described in the preparation. The crystals were manipulated in the glovebox under a microscope in the glovebox, Data collection was performed at $-80{ }^{\circ} \mathrm{C}$ on a Bruker SMART APEX diffractrometer with a CCD area detector, using graphite monochromat Mo $K_{\alpha}$ radiation $(\lambda=0.71073 \AA)$. The determination of the crystal class and unit cell parameters was carried out by the SMART program packages ${ }^{[5]}$. The raw frame data were processed using SAINT ${ }^{[6]}$ and absorption corrections using SADABS ${ }^{[7]}$ to yield the reflection data file. The structures were solved by using SHELXS-2018 ${ }^{[8]}$, SUPERFLIP ${ }^{[9]}$ in the WinGX program package ${ }^{[10]}$. Refinements were performed on $F^{2}$ anisotropically for all the non-hydrogen atoms by the full-matrix least-squares method using SHELXL-2018 program ${ }^{[8]}$.

CCDC number 1947708(1) and 1947709 (2) contain the supplementary crystallographic data for this paper. Copies of the data can be obtained free of charge on application to CCDC, 12 Union Road, Cambridge CB21EZ, UK (fax: (+44)1223-336-033; E-mail: deposit@ccdc.cam.ac.uk). 


\section{References}

(1) Cope, A. C.; Gourley, R. N. J. Organomet. Chem. 1967, 8, 527

(2) Barker A, Barker C.C. J Chem Soc 1953; (JUL). 2034-2036

(3) Lambert, J. B.; Zhang, S. M.; Stern, C. L.; Huffman, J. C. Science 1993, 260, 1917-1918.

(4) Julia,H.; Klaus, B.;Okuda, J. J. Organomet. Chem 2007, 692, 4702-4707.

(5) SMART Software Users Guide, Version 4.21; Bruker AXS, Inc.: Madison, WI, 1997.

(6) SAINT, Version 6.45; Bruker AXS, Inc.: Madison, WI 2003.

(7) Sheldrick, G. M. SADABS, Version 2.10; Bruker AXS, Inc.: Madison, WI 2003.

(8) Sheldrick, G. M. "Crystal structure refinement with SHELXL." Acta Cryst. 2015, C71, 3-8.

(9) (a) Palatinus, L.; Chapuis, G. "SUPERFLIP - a computer program for the solution of crystal structures by charge flipping in arbitrary dimensions." J. Appl. Cryst. 2007, 40, 786-790; (b) Palatinus, L., Prathapa, S. J.; van Smaalen, S. "EDMA: a computer program for topological analysis of discrete electron densities." J. Appl. Cryst. 2012, 45, 575-580.

(10) Farrugia, L. J. "WinGX and ORTEP for Windows: an update." J. Appl. Cryst. 2012, 45, 849-854. 


\section{Tables of crystal data and structure refinement}

Table S1. Crystal data and structure refinement for Complex 1.

Identification code

CCDC number

Empirical formula

Formula weight

Temperature

Wavelength

Crystal system, space group

a

b

c

$\alpha$

$\beta$

$\gamma$

Volume

$Z$, Calculated density

Absorption coefficient

$\mathrm{F}(000)$

Crystal size

Theta range for data collection

Limiting indices

Reflections collected / unique

Completeness to theta

Absorption correction

Max. and min. transmission

Refinement method

Data / restraints / parameters

Goodness-of-fit on $\mathrm{F}^{2}$

Final $\mathrm{R}$ indices [I $>2 \operatorname{sigma}(\mathrm{I})]$

$\mathrm{R}$ indices (all data)

Largest diff. peak and hole

\section{D195}

1947708

$\mathrm{C}_{25} \mathrm{H}_{41} \mathrm{Cl}_{1} \mathrm{~N}_{1} \mathrm{O}_{1} \mathrm{Sc}_{1} \mathrm{Si}_{1}$

480.09

193(2) K

$0.71073 \AA$

Monoclinic, P2(1)/c

14.8573(13) A

8.7978(7) $\AA$

20.6966(18) $\AA$

$90^{\circ}$

$101.1280(10)^{\circ}$

$90^{\circ}$

2654.4(4) $\AA^{3}$

4, $1.201 \mathrm{Mg} / \mathrm{m}^{3}$

$0.439 \mathrm{~mm}^{-1}$

1032

$0.210 \times 0.150 \times 0.130 \mathrm{~mm}$

1.397 to $24.999^{\circ}$

$-17<=\mathrm{h}<=17,-10<=\mathrm{k}<=7,-24<=1<=22$

$13165 / 4661[\mathrm{R}(\mathrm{int})=0.0279]$

$\left(24.999^{\circ}\right) 99.4 \%$

Empirical

0.945 and 0.924

Full-matrix least-squares on $\mathrm{F}^{2}$

4661 / 0 / 271

1.037

$\mathrm{R} 1=0.0499, \mathrm{wR} 2=0.1329$

$\mathrm{R} 1=0.0603, \mathrm{wR} 2=0.1427$

0.555 and -0.416 e. $\AA^{-3}$ 
Table S2. Crystal data and structure refinement for Complex 2.

\begin{tabular}{ll}
\hline Identification code & $\mathrm{D} 230$ \\
CCDC number & 1947709 \\
Empirical formula & $\mathrm{C}_{50} \mathrm{H}_{80} \mathrm{Cl}_{2} \mathrm{~N}_{2} \mathrm{O}_{2} \mathrm{Sc}_{2} \mathrm{Si}_{2}$ \\
Formula weight & 958.16 \\
Temperature & $193(2) \mathrm{K}$ \\
Wavelength & $0.71073 \AA$ \\
Crystal system, space group & Triclinic, $\mathrm{P}-1$ \\
$\mathrm{a}$ & $11.2926(14) \AA$ \\
$\mathrm{b}$ & $14.8104(18) \AA$ \\
$\mathrm{c}$ & $16.260(2) \AA$ \\
$\alpha$ & $79.750(3)^{\circ}$ \\
$\beta$ & $89.746(2)^{\circ}$ \\
$\gamma$ & $77.906(3)^{\circ}$ \\
Volume & $2615.1(6) \AA^{3}$ \\
Z, Calculated density & $2,1.217 \mathrm{Mg} / \mathrm{m}^{3}$ \\
Absorption coefficient & $0.446 \mathrm{~mm}{ }^{-1}$ \\
F(000) & 1028 \\
Crystal size & $0.210 \times 0.180 \times 0.150 \mathrm{~mm}$ \\
Theta range for data collection & 1.273 to $24.9999^{\circ}$ \\
Limiting indices & $-13<=\mathrm{h}<=12,-17<=\mathrm{k}<=12,-19<=1<=19$ \\
Reflections collected / unique & $13538 / 9011[\mathrm{R}(\mathrm{int})=0.0596]$ \\
Completeness to theta & $\left(24.9999^{\circ}\right) 97.8 \%$ \\
Absorption correction & Empirical \\
Max. and min. transmission & 0.935 and 0.911 \\
Refinement method & Full-matrix least-squares on $\mathrm{F}^{2}$ \\
Data / restraints / parameters & $9011 / 1 / 535$ \\
Goodness-of-fit on F & 0.986 \\
Final R indices [I $>2$ sigma(I)] & $\mathrm{R} 1=0.0770, \mathrm{wR} 2=0.1594$ \\
$\mathrm{R}$ indices (all data) & $\mathrm{R} 1=0.1509, \mathrm{wR} 2=0.1995$ \\
Largest diff. peak and hole & 0.616 and $-0.600 \mathrm{e} . \AA^{-3}$ \\
\hline
\end{tabular}




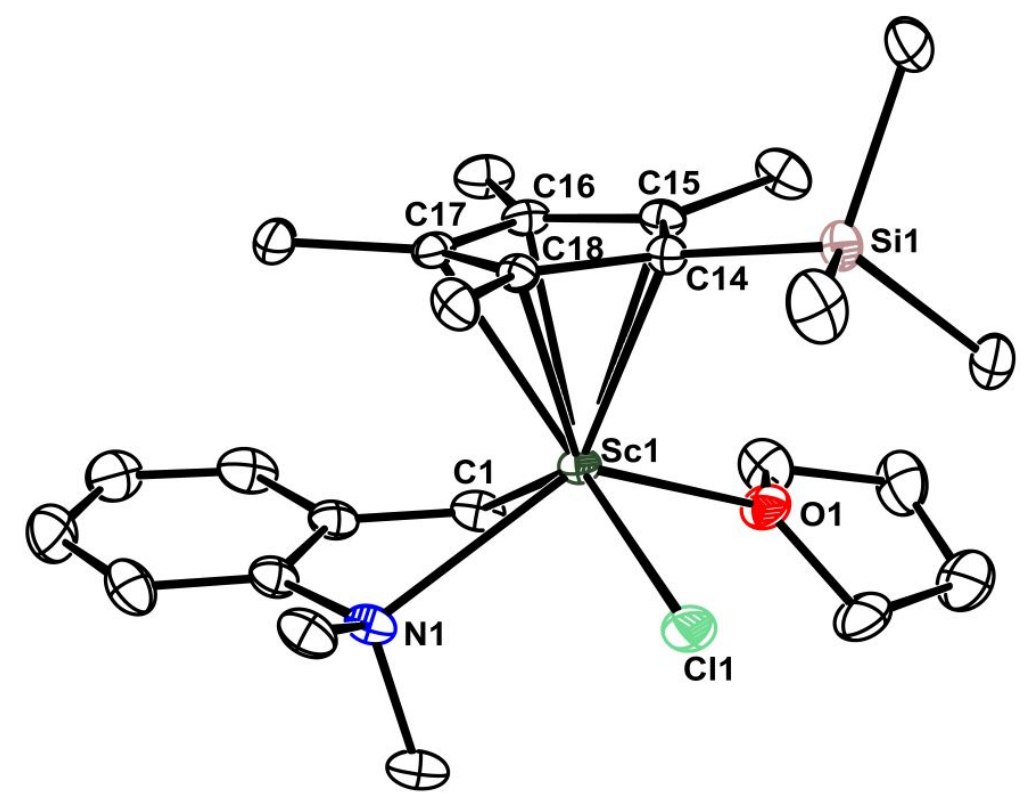

Figure S18. ORTEP drawing of half-sandwich scandium aminobenzyl/chloride complexes 1 with thermal ellipsoids set at $20 \%$ probability. All the hydrogen atoms are omitted for clarity. Selected interatomic distances $[\AA]$ : Sc1-C1 2.276(3), Sc1-Cl1 2.4637(8), Sc1-N1 2.515(2), Sc1-O1 2.263(2), Sc1-C14 2.471(2), Sc1-C15 2.502(2), Sc1-C16 2.521(2), Sc1-C17 2.516(2), Sc1-C18 2.482(2), Sc1Cent 2.188, (Cent: Centre of the Cp' ring).

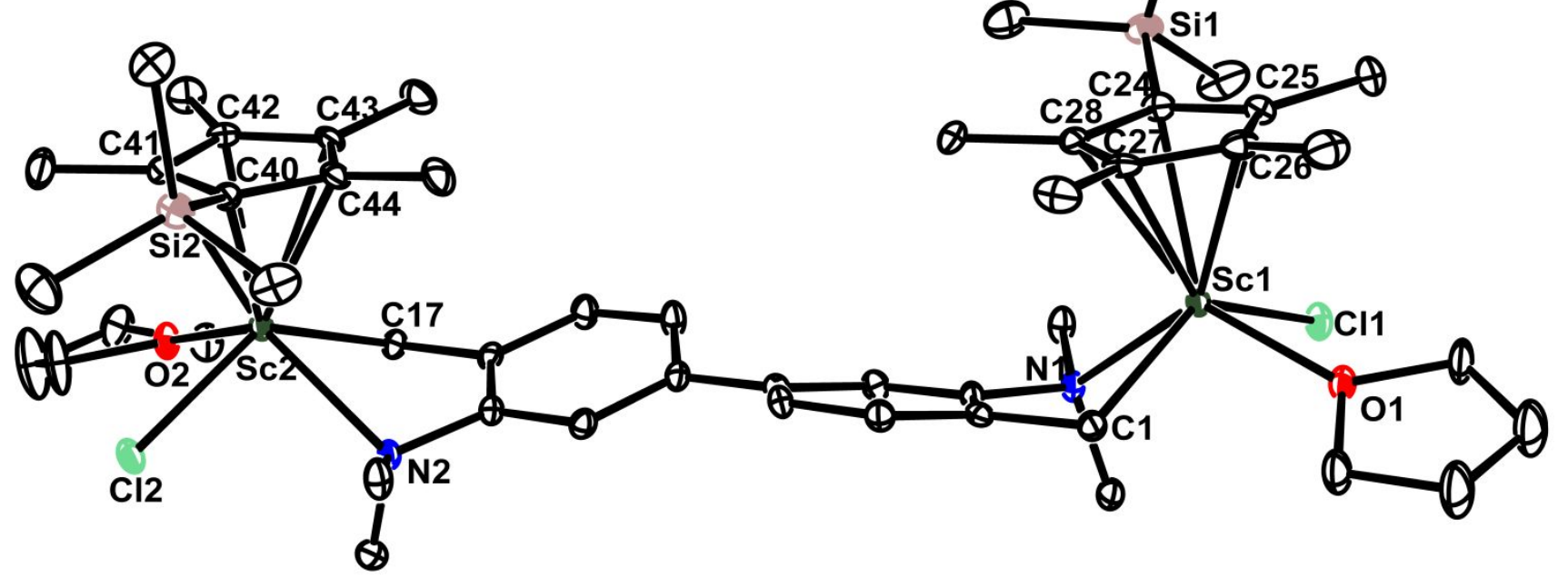

Figure S19. ORTEP drawing of half-sandwich scandium aminobenzyl/chloride complexes 2 with thermal ellipsoids set at $20 \%$ probability. All the hydrogen atoms are omitted for clarity. Selected interatomic distances $[\AA]$ : Sc1-C1 2.266(5), Sc1-Cl1 2.4753(18), Sc1-N1 2.454(4), Sc1-O1 2.262(4), Sc1-C24 2.492(6), Sc1-C25 2.474(6), Sc1-C26 2.513(6), Sc1-C27 2.533(6), Sc1-C28 2.521(6), Sc1Cent1 2.197; Sc2-C17 2.265(5), Sc2-Cl2 2.4732(17), Sc2-N2 2.465(5), Sc2-O2 2.262(4), Sc2-C40 2.477(6), Sc2-C41 2.462(6), Sc2-C42 2.529(6), Sc2-C43 2.552(5), Sc2-C44 2.529(6), 'Sc2-Cent2 2.201 (Cent1: Centre of the Cp' ring (C24-C28, Cent2: Centre of the Cp' ring(C40-C44)). 